\title{
THE MALE OF ECITON VAGANS OLIVIER.
}

\author{
By William Morton Wheeler, \\ Bussey Institution, Harvard University.
}

Only the worker form of Eciton vagans is known, although it was first described by Olivier as long ago as $\mathbf{1 7 9 1}$ and is one of the most abundant and conspicuous legionary ants of tropical America from Mexico to Southern Brazil. That its female has never been seen is not surprising, because female Ecitons are among the rarest of insects, but it is strange that the male of such a common insect should not have been described as one of the numerous species of Labidus, a genus to which all male Ecitons were referred by Latreille, Westwood and other entomologists of the first half of the nineteenth century. The only described male, however, that may prove to belong to $E$. vagans, is $E$. dubitatum Emery (vide infra), but this is by no means certain.

November 29, 1911, while collecting ants at La Sabana, a suburb of San José, Costa Rica, I came upon a small army of E.vagans rapidly ascending the grassy slope of a ravine. While $\mathrm{I}$ was watching the rust-red workers a large chocolate brown male with infuscated wings came marching along in the file, and a few moments later another appeared alternately flitting and walking in the grass about a foot away from its worker companions but moving in the same direction. There could be no doubt that these two insects were accompanying the army and that they belonged to the same species as the workers, because the most careful search revealed no other Ecitons on the whole grassy slope of several acres. Moreover, it was not the regular season for forays of these ants, for I encountered very few species of the genus in Panama, Costa Rica and Guatemala during November, December and January. Only E. coecum Latr., which is a subterranean species, seems not to interrupt its forays during these months. I append a description of the two males which I captured. 
Eciton vagans Olivier.

Male. Length 15-16 mm.

Head transverse, nearly twice as broad as long, very nearly as broad as the thorax; broadly arcuate behind, its anterior border broadly and arcuately excised Eyes and ocelli rather small, the former less convex than in many species. Frontal carinæ very short, not carried up on the front or curving outward behind the antennal insertions. Mandibles long, as long as the transverse diameter of the head, flat, straight and with subparallel borders, except at the tip, which is curved and pointed, with a single large, triangular tooth about 2-3 the distance from the base to the tip. Antennæ rather slender, first funicular joint not more than half as long as the second. Thorax only moderately convex above, not overarching and concealing the head when the insect is seen from above. Mesonotum with distinct parapsidal and median longitudinal furrows. Scutellum and metanotum very convex, each longitudinally impressed in the middle. Epinotum abruptly sloping, with a blunt transverse protuberance on each side. Petiole twice as broad as long, much narrower in front than behind, deeply concave in the middle above, with prominent anterior and posterior angles, the latter projecting considerably. Gaster rather short and thick. Hypopygium terminating behind in two claw-like teeth. Hind legs long, the tips of their femora surpassing the posterior border of the second gastric segment. Claws of tarsi not dentate as in the worker.

Mandibles, head, thorax, antennæ and legs opaque, very finely and densely punctate; mandibles, head and mesonotum also with more scattered, coarser, piligerous punctures. Petiole and gaster shining, finely shagreened.

Hairs fulvous; long only on the posterior surfaces of the fore coxæ and femora, on the mandibles, head and anterior border of the scutellum; short, subreclinate and denser on the mesonotum, tip of gaster, posterior corners of petiole and ventral surfaces of m ddle coxæ; absent on the pronotum and pleuræ. Antennal scapes, petiole and gaster with only very short and delicate pubescence which is not sufficiently dense to conceal the surface.

Mandibles, head, scapes, thorax, petiole and gaster dark chocolate brown; funiculi, tarsi and tibiæ light yellowish brown; femora darker. Wings rather deeply infuscated, with resin-brown veins and stigma.

This form agrees in many particulars with the description of E. dubitatum Emery from Paraguay (Bull. Soc. Ent. Ital. XXVIII, 1896, p. 8). The shape of the mandibles is the same as is evident from comparison with Emery's figure, but there are numerous differences in sculpture, pilosity and coloration. Emery believed that his dubitatum might be the male of $E$. vagans Oliv. or of $E$. rogeri Dalla Torre, but in his latest contribution (Genera Insect. Dorylinæ, p. 20) he cites it only as the possible male of the latter species. 

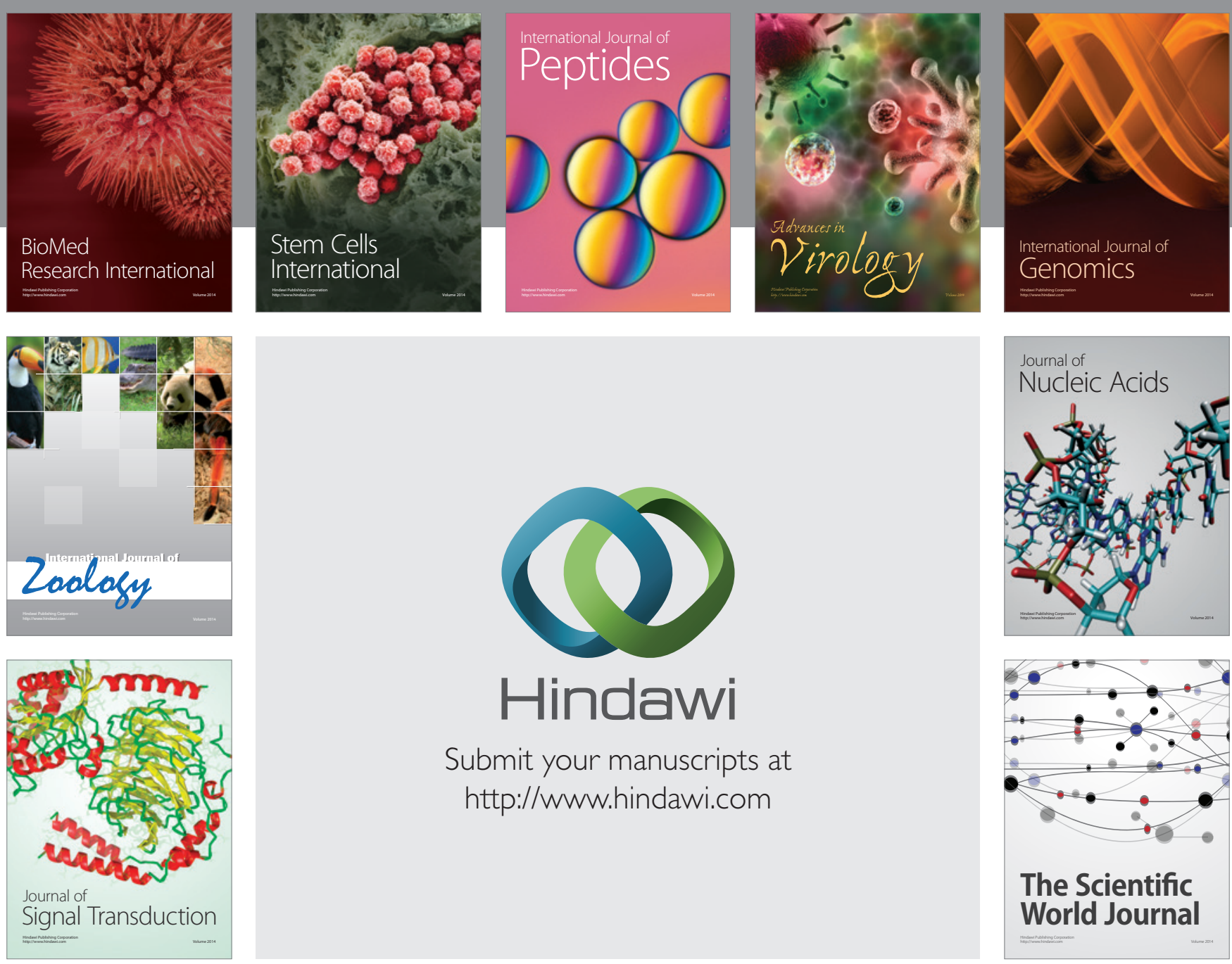

Submit your manuscripts at

http://www.hindawi.com
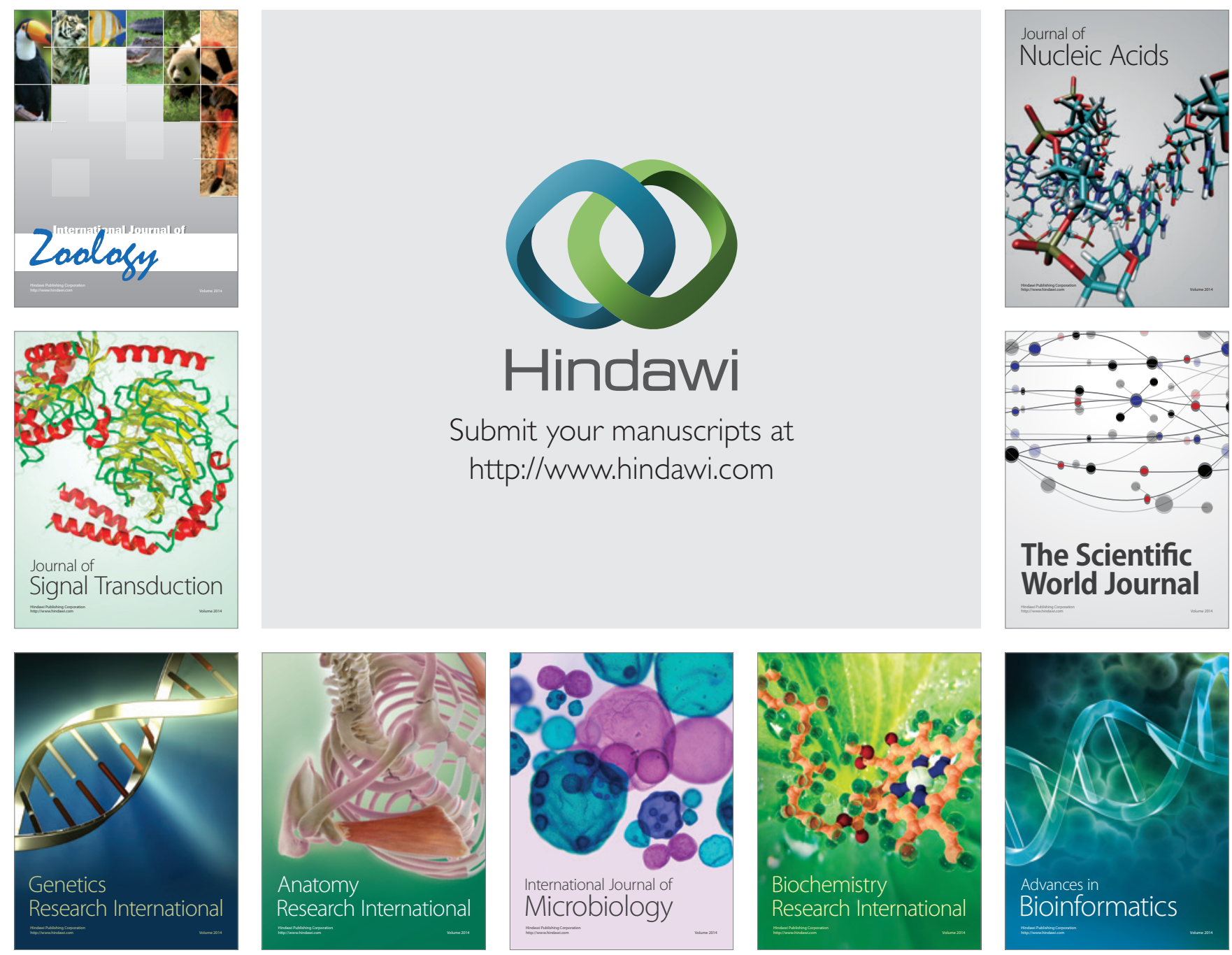

The Scientific World Journal
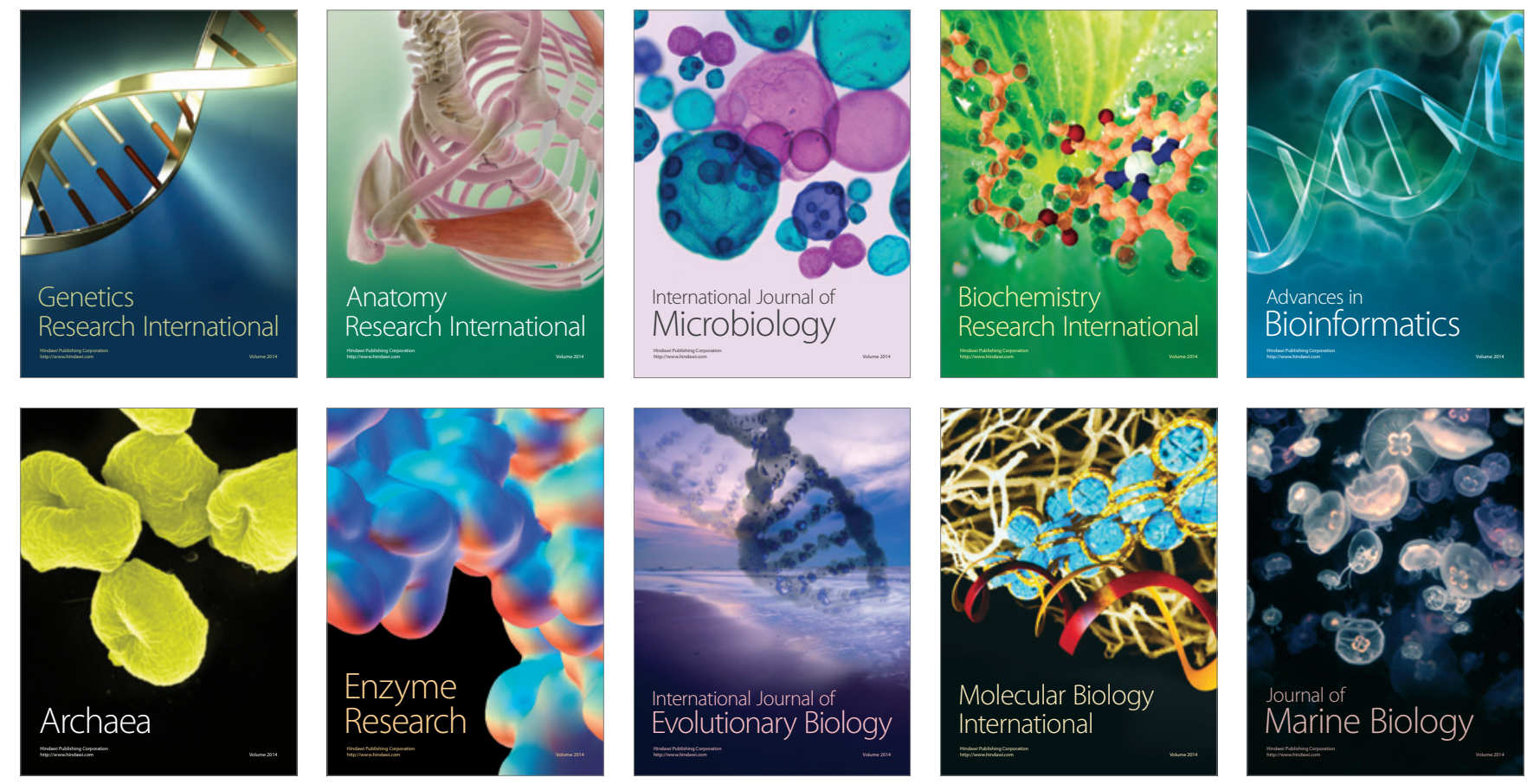